\title{
The little auk Alle alle polaris of Franz Josef Land: a comparison with Svalbard Alle a. alle populations
}

\author{
L. STEMPNIEWICZ, M. SKAKUJ and L. ILISZKO
}

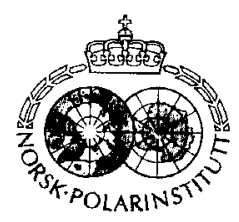

\begin{abstract}
Stempniewicz, L., Skakuj, M. \& Iliszko, L. 1996: The little auk Alle alle polaris of Franz Josef Land: a comparison with Svalbard Alle a. alle populations. Polar Research 15(1), 1-10

Breeding biology, nestling growth and development, and biometry of the little auk Alle alle polaris were studied in Franz Josef Land. A total of 103 adult birds were measured, 60 in the field and 43 in the St. Petersburg Museum. The development of 16 chicks was compared with that of Alle a. alle chicks from Spitsbergen. At particular stages of development, both adults and nestlings of $A$. a. polaris are larger than those of $A$, a. alle.

In Franz Josef Land the breeding season is more extended and less synchronised than that of Svalbard. The majority of the little auks in the studied colonies in Franz Josef Land nested on steep rocky cliffs, possibly as an adaptation to the severe climatic conditions and heavy mammalian predation in subcolonies located on accessible mountain slopes. Glaucous gulls Larus hyperboreus exerted negligible predatory pressure. This study confirms the existence of morphologically distinguishable populations of the little auk on Franz Josef Land and Svalbard, supported by recent studies of climatic and oceanographic conditions in the two areas that parallel the morphological differentiation.
\end{abstract}

Lech Stempniewicz, Michat Skakuj and Lech lliszko, Department of Vertebrate Ecology and Zoology, University of Gdańsk, Legionów 9, 80-441 Gdanisk, Poiand.

\section{Introduction}

There are several examples of intrageneric differentiation in the Alcidae. For example, the genus Uria has two closely related sister species, the common guillemot Uria aalge and the Brünnich's guillemot $U$. lomvia. Although their breeding ranges overlap widely, $U$. aalge tends to be boreal and $U$. lomvia tends to be polar. Morphology, biology, food and behaviour are very similar though some differences exist, especially where the ranges overlap (Salomonsen 1944; Storer 1952; Spring 1971; Bédard 1985; Strauch 1985; Birkhead \& Nettleship 1987a, b, c). Closely related species are also found in the genera Cepphus and Fratercula, but these are geographically separated. The Pacific Ocean is inhabited by two Cepphus species and two Fratercula species, whereas the black guillemot Cepphus grylle and Atlantic puffin Fratercula arctica occur in the Atlantic Ocean.

There are also several examples of intraspecific differentiation within the genera Cepphus and Uria. For instance, Storer (1952) has recognised six subspecies of black guillemot, seven subspecies of common guillemot and two subspecies of Brünnich's guillemot.
On the basis of size, Stenhouse (1930) described A. a. polaris, a subspecies of the little auk Alle alle, as originating from Franz Josef Land. The ten specimens measured by Stenhouse (1930) showed greater mean body dimensions (wing length, bill length and width and tarsus length) than those of the nominate subspecies $A$. a. alle which inhabits Greenland, Novaja Zemlja and Svalbard. Since Stenhouse's (1930) paper, Russian workers have collected and measured forty additional specimens from Franz Josef Land and two from Severnaja Zemlja. The latter area is conjectured to be a breeding area of subspecies polaris (Dement'ev 1951; Kozlova 1957; Flint \& Golovkin 1990). Until the present, the taxonomic position of little auks from these regions has remained uncertain and has been questioned (Bédard 1985).

The aim of this study was to compare measurements of adults and to analyse growth and development of nestling little auks which inhabit Svalbard (Spitsbergen and Bjørnøya) and Franz Josef Land, where the subspecies alle and polaris, respectively, breed. Aspects of the little auks' breeding biology were also studied and compared. The results of this study may be useful in understanding patterns and processes of intraspecific differentiation in the little auk. 


\section{Materials and methods}

Biometrical data were obtained during three expeditions to Franz Josef Land (21 August-7 September 1991, 15 August-5 September 1992, and 17 August-4 September 1993). Fifteen birds were collected in August 1991 in the colony at Rubini Rock (Hooker Island, $80^{\circ} 47^{\prime} \mathrm{N}$ ). Fortyone birds were collected in August 1992 (34 at Hooker Island; 3 at Prince George Land, 80$81^{\circ} \mathrm{N}, 2$ at Northbrook Island, $80^{\circ} \mathrm{N} 51^{\prime} \mathrm{E}$ and 2 at Kane Island, $81^{\circ} \mathrm{N}$ ). Four birds were collected in August 1993 at Brady Island $\left(80^{\circ} \mathrm{N}\right)$. In total 60 individuals were measured in the field, including 14 netted and 46 shot for parasitological, toxicological and food content analyses. In addition one of the authors, M. Skakuj, measured 45 specimens which had bee housed for ca. 60 years in the collection of the Institute of Zoology of the Russian Academy of Sciences in St. Petersburg. The specimens included 43 adult little auks from Franz Josef Land and 2 from Severnaja Zemlja.

The little auks from Spitsbergen $(n=99)$ were caught and measured during five expeditions to Hornsund $\left(77^{\circ} \mathrm{N}\right)$ : 15 June-4 September 1974, 27 June-9 September 1975, 13 May-20 August 1980, 30 July-27 August 1983, and 10-13 August 1992). The results have been published in part in an earlier paper (Stempniewicz 1981). During the expedition to Bjørnøya, 5-30 July 1994, 272 little auks, including 219 adults and 53 subadults, were netted and measured in the colony at Alfredfjellet $\left(74^{\circ} 15^{\prime} \mathrm{N}, 19^{\circ} 03^{\prime} \mathrm{E}\right)$. Subadult birds were distinguished from adults by external features such as colour and wear of primaries, secondaries, wing coverts and tail-feathers (Roby et al. 1981; Bradstreet 1982; Bédard 1985). Measurements of subadult birds were excluded from the interpopulation comparisons. Measurements were taken in the field by L. Stempniewicz. All birds collected were thoroughly examined and then (shot birds) sectioned in the laboratory. Age (two groups: subadults, birds in their second calendar year, and adults, older birds) and sex of birds were determined. Sex determination was only possible for shot birds. Measurements included body mass (with accuracy to $1 \mathrm{~g}$ ), wing length (naturally folded wing and maximally flattened and stretched wing, adapted to little auks from Svensson 1975), bill length (from tip to feathering), head length (from bill tip to occiput; measured only in Bjørnøya birds), tail length (from root to tip of longest tail-feathers, when naturally folded, adapted to little auks from Svensson 1975) and tarsus length (with accuracy to $1 \mathrm{~mm}$ ).

Egg biometry is based on 99 eggs measured in Spitsbergen, 15 eggs measured on Bjørnøya, and 18 measurements from Franz Josef Land taken from Gorbunov (1932). The maximal length (L) and breadth (B) of eggs were measured and then volume index (V) was calculated using formula $\mathrm{V}=\Pi / 6{ }^{*} \mathrm{LB}^{2} / 1000$.

Chick growth and development were studied in August 1992 in the colony at Rubini Rock, Hooker Island. Measurements of wing, bill, tarsus, tail and body mass were taken and plumage development described every second day in the nestlings from 16 marked nests. Other data about chick development as well as little auk breeding biology in Spitsbergen were taken from earlier papers (Stempniewicz 1980, 1981, 1986). Statistical comparisons were made using a t-test, assuming normal distribution of data and equal variances of the samples.

Moreover, breeding phenology (dates of egg hatching, fledging of the young), activity rhythm (attendance at colony, feeding) and predation by glaucous gulls Larus hyperboreus (number and percent of successful attacks) were studied and compared in the three areas (Spitsbergen, Bjørnøya and Franz Josef Land). For methodological details see Stempniewicz (1986, 1995).

\section{Results}

\section{Measurements of adult and subadult birds}

Table 1 presents statistics of measurements of adult little auks from Hornsund (Spitsbergen), Bjørnøya and Franz Josef Land. The last were separated into those taken on birds in the field and those from museum skins. Subadult birds were not included in Table 1 , as they are significantly smaller than adults. Fifty-three subadult birds measured in Bjørnøya differed significantly from adults $(n=212-219)$ in all body measurements (t-test, 2-tailed $\mathrm{P}<0.005$ ), except for tarsus length $(P=0.32)$. There was, however, a considerable overlap in all measurements between the two age groups. Sex-related differences in adult body size were not evident (t-test, 2-tailed $P>0.05$ ), except for body mass of the Spitsbergen birds ( $\mathrm{df}=18, \mathbf{P}<0.001)$. 
Table 1. Statistics of measurements of adult little auks Alle alle from Spitsbergen, Bjørnøya and Franz Josef Land. Body mass in $\mathrm{g}$, length measurements in $\mathrm{mm}$. Wing nat. = naturally folded wing. Sec Table 2 for results of statistical tests.

\begin{tabular}{|c|c|c|c|c|c|c|}
\hline Area & Sample & Variable & Mean & $\mathrm{SD}$ & Range & $\mathbf{N}$ \\
\hline Spitsbergen & Field & \multirow[t]{4}{*}{ Mass } & 163.0 & 11.35 & $134.0-192.5$ & 94 \\
\hline Biørnøya & Field & & 157.8 & 10.53 & $133.0-196.0$ & 212 \\
\hline Franz Josef Land & Field & & 202.3 & 12.48 & $174.0-230.0$ & 56 \\
\hline Franz Josef Land & Museum & & - & - & - & - \\
\hline Spitsbergen & Field & \multirow[t]{4}{*}{ Wing nat. } & 120.9 & 3.27 & $114.0-129.0$ & 94 \\
\hline Bjørnøya & Field & & 120.4 & 2.47 & $113.0-129.0$ & 219 \\
\hline Franz Josef Land & Field & & 128.0 & 3.83 & $116.0-136.0$ & 58 \\
\hline Franz Josef Land & Museum & & - & - & - & - \\
\hline Spilsbergen & Field & \multirow[t]{4}{*}{ Wing $\max$} & 124.6 & 2.51 & $121.0-127.0$ & 5 \\
\hline Bjørnøya & Field & & 124.8 & 2.64 & $118.0-133.5$ & 217 \\
\hline Franz Josef Land & Field & & 133.3 & 3.73 & $122.0-141.0$ & 59 \\
\hline Franz Josef Land & Museum & & 131.6 & 3.07 & $124.0-139.0$ & 41 \\
\hline Spitsbergen & Field & \multirow[t]{4}{*}{ Tail } & 33.6 & 2.46 & $27.0-38.0$ & 88 \\
\hline Bjørnøya & Field & & 34.4 & 1.59 & $30.0-39.0$ & 219 \\
\hline Franz Josef Land & Field & & 38.3 & 1.24 & $35.0-41.0$ & 41 \\
\hline Franz Josef Land & Museum & & - & - & - & - \\
\hline Spitsbergen & Field & \multirow[t]{4}{*}{ Bill } & 15.9 & 0.71 & $14.0-17.5$ & 88 \\
\hline Bjørnøya & Field & & 15.3 & 0.82 & $13.0-17.5$ & 217 \\
\hline Franz Josef Land & Field & & 17.4 & 1.19 & $14.7-19.5$ & 57 \\
\hline Franz Josef Land & Museum & & 15.9 & 1.03 & $14.0-18.0$ & 32 \\
\hline Spitsbergen & Field & \multirow[t]{4}{*}{ Tarsus } & 21.8 & 0.81 & $20.0-23.5$ & 94 \\
\hline Bjørnøya & Field & & 21.4 & 0.86 & $16.5-23.5$ & 214 \\
\hline Franz Josef Land & Field & & 23.1 & 0.84 & $21.4-25.5$ & 51 \\
\hline Franz Josef Land & Muscum & & 21.6 & 0.93 & $20.0-23.0$ & 42 \\
\hline
\end{tabular}

Note: Data are not segregated by sex as a majority of the birds were not sex-determined.

However, small sample of sex-determined birds makes the comparison difficult.

In general, birds from Franz Josef Land were heavier and larger than those from Svalbard. Evident differences in measurements (taken in the field) between birds from Svalbard and those from Franz Josef Land have been found ( $t$-test, $P<0.001$ ). Moreover, little auks from Bjørnøya were lighter and had shorter bill and tarsus than those of Spitsbergen (Table 2).

Skin measurements of Franz Josef Land birds showed intermediate values, presumably due to shrinkage and somewhat different methods of measuring live or freshly dead birds versus skins, making it difficult to compare the two kinds of samples. As a result, wing length (maximal length) of the skins was significantly shorter than maximal wing length of birds caught and measured in the field (Franz Josef Land). Also, bill length and tarsus length were significantly shorter in Franz Josef Land skins than in those measured in the field. Moreover, skins from Franz
Table 2. Differences in measurements (taken in the field) of adult little auks Alle alle from Spitsbergen, Bjørnøya and Franz Josef Land: Body mass in g, length measurements in mm. Wing nat.$=$ naturally folded wing. See Table 1 for data.

\begin{tabular}{llrl}
\hline Area & Variable & \multicolumn{1}{c}{$\mathrm{t}$} & P (2-tailed) \\
\hline Bjørnøya & Mass & -3.92 & 0.000 \\
versus & Wing nat. & -1.47 & 0.141 \\
Spitsbergen & Wing max. & 0.17 & 0.866 \\
& Tail & 3.24 & 0.001 \\
& Bill & -6.71 & 0.000 \\
& Tarsus & -3.49 & 0.000 \\
Bjørnøya & Mass & -27.02 & 0.000 \\
versus & Wing nat. & -18.42 & 0.000 \\
Franz Josef Land & Wing max. & -19.90 & 0.000 \\
& Tail & -14.66 & 0.000 \\
& Bill & -15.72 & 0.000 \\
& Tarsus & -12.29 & 0.000 \\
Spitsbergen & Mass & -19.74 & 0.000 \\
versus & Wing nat. & -12.26 & 0.000 \\
Franz Josef Land & Wing max. & -5.09 & 0.000 \\
& Tail & -11.37 & 0.000 \\
& Bill & -9.20 & 0.000 \\
& Tarsus & -8.95 & 0.000 \\
& & & \\
\hline
\end{tabular}


Table 3. Differences in measurements of adult little auks Alle alle from Spitsbergen, Bjørnøya and Franz Josef Land (taken in the field and in the museum). Wing nat. = naturally folded wing. Body mass in $\mathrm{g}$, length measurements in $\mathrm{mm}$.

\begin{tabular}{llrr}
\hline Area (sample) & Variable & $\mathrm{t}$ & P (2-tailed) \\
\hline Bjørnøya (field) & Wing nat. & -25.58 & 0.000 \\
versus & Wing max. & -14.64 & 0.000 \\
Franz Josef Land (museum) & Tarsus & -1.37 & 0.172 \\
Spitsbergen (field) & Bill & -4.04 & 0.000 \\
versus & Wing nat. & -17.84 & 0.000 \\
Franz Josef Land (museum) & Wing max. & -4.87 & 0.000 \\
Franz Josef Land (field) & Tarsus & 1.04 & 0.301 \\
versus & Bill & 0.12 & 0.904 \\
Franz Josef Land (museum) & Wing nat. & -5.12 & 0.000 \\
& Wing max. & 2.53 & 0.013 \\
\hline
\end{tabular}

Note: Wing length in skins was taken (as far as possible) as maximum wing length.

Josef Land did not differ significantly from Svalbard specimens measured in the field as regards bill length and tarsus length (Spitsbergen) and tarsus length (Bjørnøya) (Table 3).

Multivariate analysis showed that any set of two variables measured in the field clearly discriminates the little auk populations from Franz Josef Land and Svalbard (ANOVA, $\mathrm{P}<0.001$ ). Figs. 1 and 2 illustrate discrimination of the two populations by combining body mass and wing length, and wing and bill length.

\section{Eggs and chicks}

Of the eggs measured, those from Franz Josef Land were the largest, those from Bjørnøya were the smallest, and the eggs from Spitsbergen were intermediate in size. The differences are not statistically significant. The samples are, however, relatively small. Differences are more evident in egg breadth than length (Table 4).

This study is the first to address the development of little auk chicks in Franz Josef Land. The material we have obtained permits us to make general comparisons with Spitsbergen nestlings. Little auk nestlings in Franz Josef Land attained significantly higher mean values of body mass and wing bill, tarsus and tail lengths in subsequent days of their lives than pitsbergen chicks ( $t$-test, $P<0.05$ ). The curves, however, have similar slopes, suggesting the same mode of chick growth and development in either locality (Figs. 3 and 4).

Twenty-five percent of the chicks observed in Franz Josef Land belonged to the white-bibbed form and another $25 \%$ showed intermediate plumage with ash-grey throats. These figures are much higher than in the case of nestlings studied

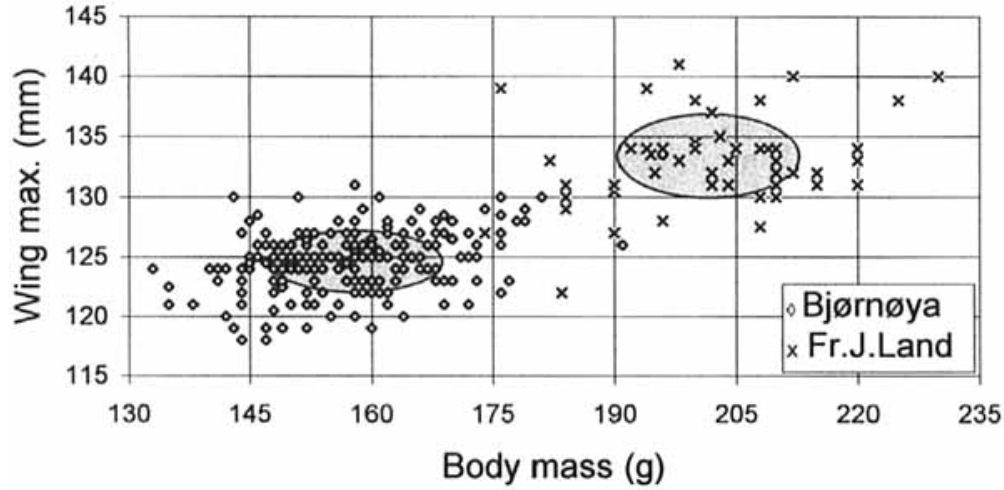

Fig. I. Body mass maximal wing length relationship in adult little auks Alle alle from Franz Josef Land and Bjornøya Dark ovals contain mean values and standard deviation ranges. 
Fig. 2. Maximal wing length - bill length relationship in adult little auks Alle alle from Franz Josef Land and Bjørnøya. Dark ovals contain mean values and standard deviation ranges.

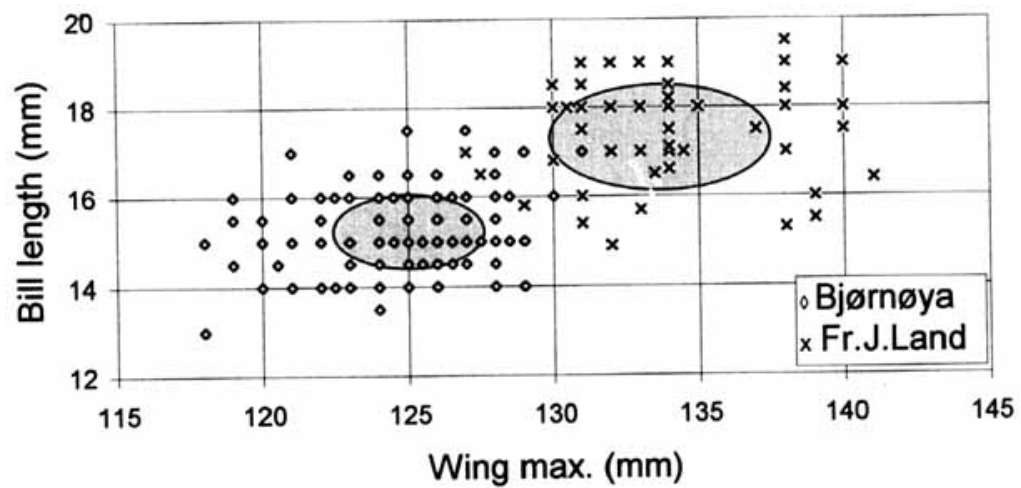

Table 4. Little auk Alle alle egg measurements. Length and breadth in $\mathrm{mm}$, volume in $\mathrm{cm}^{3}$.

\begin{tabular}{lllll}
\hline Area & Variable & Mean & SD & Range \\
\hline Franz Josef Land & Length & 49.29 & 1.85 & $45.9-52.5$ \\
$(1914 ; \mathbf{n}=18)$ & Breadth & 34.63 & 1.17 & $32.8-36.8$ \\
& Volume & 31.00 & 2.87 & $26.3-36.0$ \\
Spitsbergen & Length & 48.99 & 1.88 & $45.0-54.4$ \\
$(1974-75 ; n=99)$ & Breadth & 33.91 & 0.87 & $31.8-35.9$ \\
& Volume & 29.49 & 2.19 & $24.8-34.7$ \\
Bjørnøya & Length & 48.53 & 2.61 & $43.6-53.7$ \\
$(1994 ; n=15)$ & Breadth & 33.68 & 1.76 & $28.9-36.6$ \\
& Volume & 29.01 & 4.25 & $19.1-37.6$ \\
\hline
\end{tabular}

in Hornsund, Spitsbergen (10\%) (Stempniewicz 1989).

\section{Phenology}

Fresh eggs have been found in Franz Josef Land as early as 9 June and as late as $14 \mathrm{July}$ (egg laying span 35 days) (Gorbunov 1932; Demme 1934). Egg laying in Hornsund in 1974 and 1975 covered only 15 days. It started about ten days later (18 June in 1974) and was completed about ten days earlier (3 July in 1975) (Stempniewicz 1981). Hatching has been observed in Franz Josef Land as late as in the first days of August i.e. about 1020 days later than in Hornsund (Norderhaug 1980; Stempniewicz 1981). In 1992, timing of hatching in the colony at Rubini Rock was calculated to span the period 31 July-7 August, based on growth and developmental features of 16 nestlings studied during the period 16 August-3 September. In Franz Josef Land, birds began to leave
Fig. 3. Comparison of the little auk chick body mass growth (mean \pm SD) in Franz Josef Land $(\mathrm{n}=$ 14-16; for chicks older than 23 days, $n=7-9$ ) and Spitsbergen ( $n=44-54$; for chicks older than 24 days, $\mathbf{n}=9-37$; data from Stempniewicz 1980).

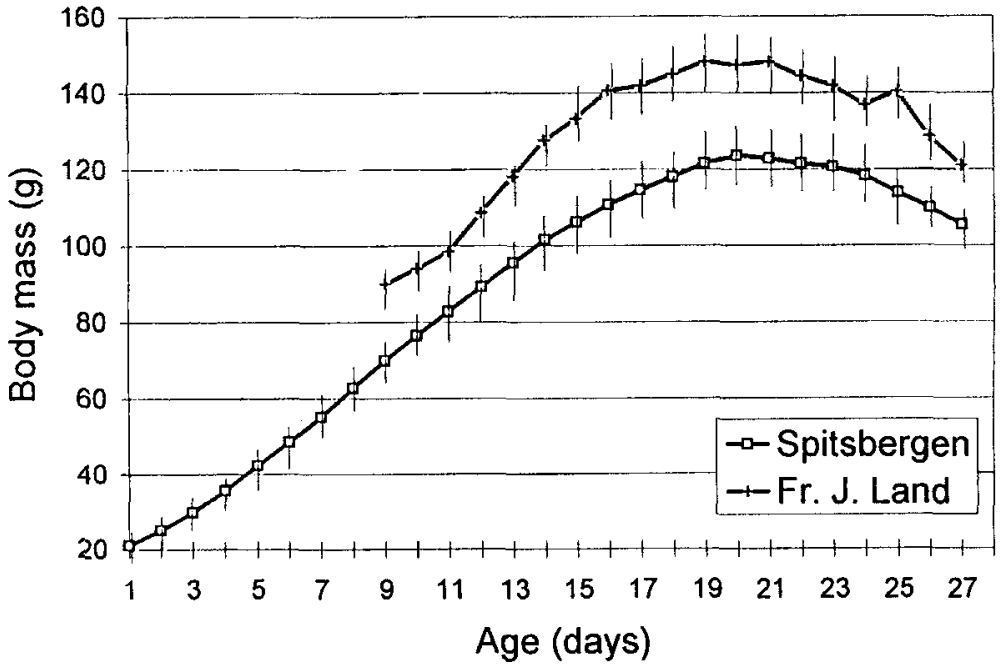




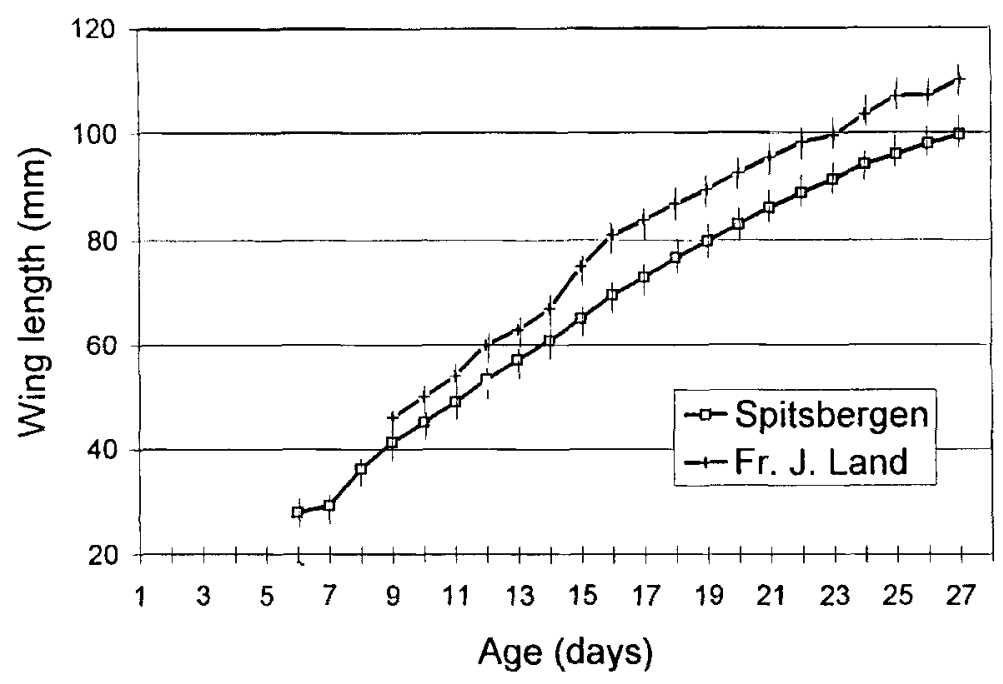

Fig. 4. Comparison of the little auk chick wing length growth (mean $\pm \mathrm{SD}$ ) in Franz Josef Land ( $\mathrm{n}=$ 14-16; for chicks older than 23 days, $n=7-9$ ) and Spitsbergen $(n=11-31$; data from Stempniewicz 1980 ). the colony about 20 days later than in Spitsbergen, i.e. on 28 August (Fig. 5).

Females apparently left the colony earlier, leaving the males to take care of the young during the chick's final days in the nest and during fledging. Twenty-three of $31(74.2 \%)$ adult little auks shot and sex-determined between 16 and 26 August
$1991 / 1992$, and all 27 adult birds shot in the vicinity of the colony later in the two seasons (i.e. between 27 August and 7 September) were males.

In the second half of August, adult little auks started moulting the black breast feathers (breeding plumage) which gradually changed into white feathers (winter plumage). On 19 August 1992 ,

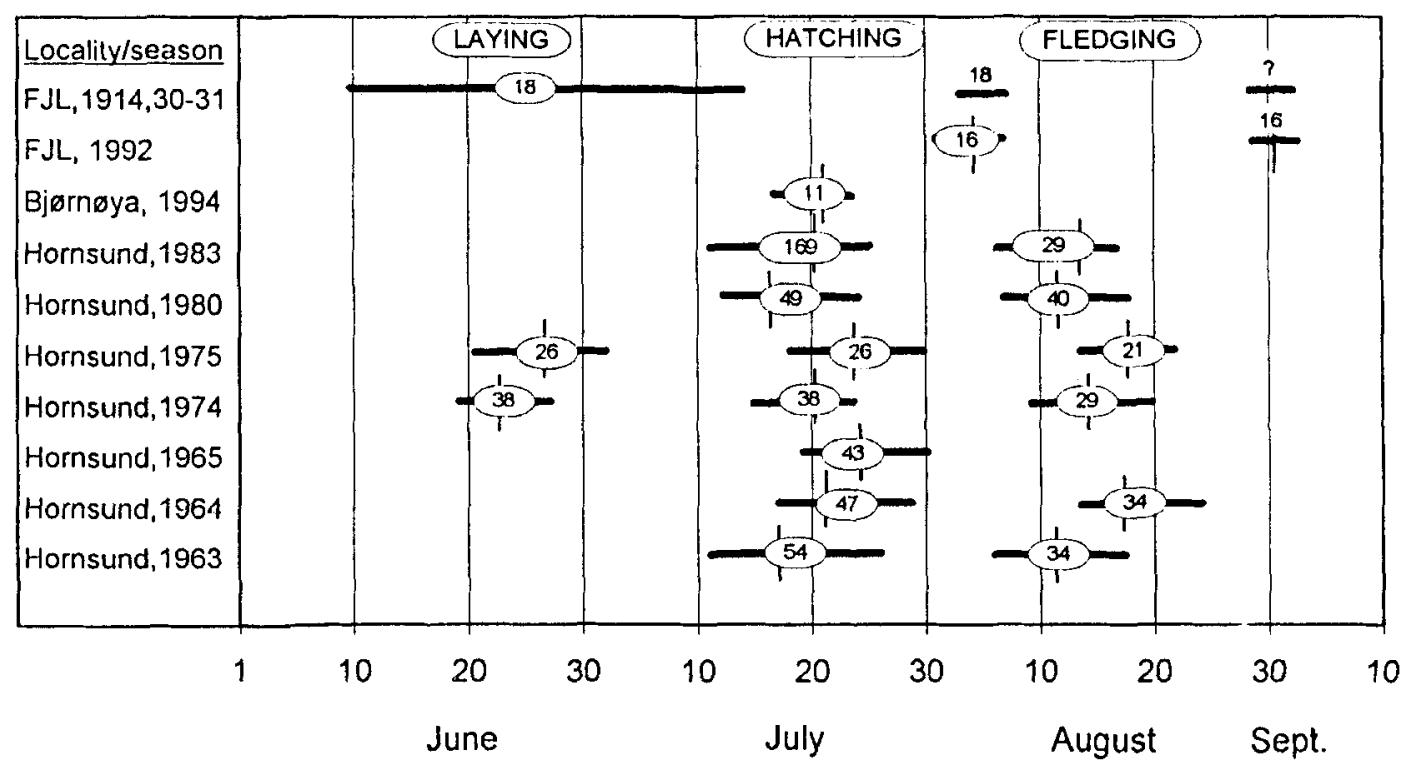

Fig. 5. Timing of egg laying, hatching and fledging of young little auks in Svalbard and Franz Josef Land (horizontal lines - ranges with numbers of nests controlled; vertical lines - medians). Data for Spitsbergen are from Norderhaug (1980) and Stempniewicz (1981, 1986, 1995; unpubl. data), for Bjørnøya from Stempniewicz (unpubl. data) and for Franz Josef Land from Gorbunov (1932), Demme (1934), and Stempniewicz (1993; unpubl. data). 


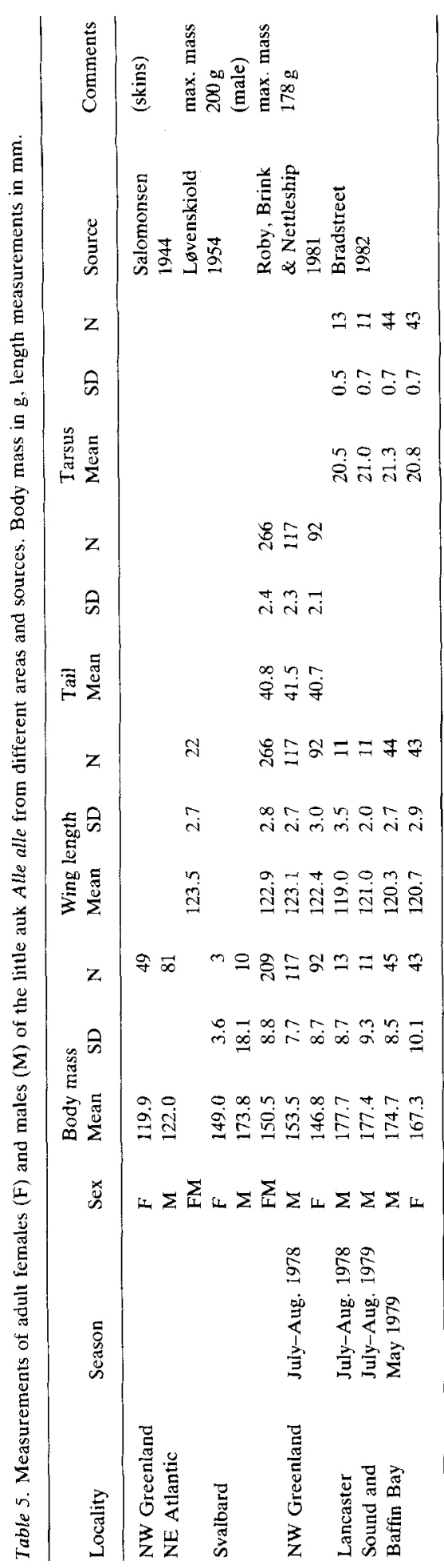

forty-one of 183 birds $(22.4 \%)$ surveyed in the colony showed distinct signs of breast feather moulting.

\section{Discussion}

The original description of the subspecies from Franz Josef Land, Alle a. polaris, was based on a small sample (Stenhouse 1930). This study confirms the existence of a morphologically distinguishable population of the little auk on Franz Josef Land. The existence of two distinct populations in Svalbard and Franz Josef Land is difficult to explain because these two land masses are both in the same high-arctic zone (Salomonsen 1972). Recent studies, however, do show differences in climatic and oceanographic conditions between these two areas that may parallel this morphological differentiation. The climate in Franz Josef Land is more severe due to the impact of two cold currents (Makarov and Arctic currents) which flow from the north, and to the relatively weak influence of the relatively warm Novaja Zemlja Current which brings remnants of Atlantic water from the south (Weslawski 1993).

Nevertheless, the distance separating these two archipelagos is small and easily covered by little auks which migrate thousands of kilometres each year (Norderhaug 1967). Partial interchange of birds between the two areas is very likely and differences in body size between the birds from Franz Josef Land and Svalbard are not absolute (Table 1, Figs. 1 and 2).

Morphological differences may be maintained or strengthened by divergent migratory habits related to recent glacial history. It is conceivable that the larger of the two subspecies, having a surface: volume ratio that is more adaptive in severe climate, could have evolved in a refugium along the Arctic coast basin, whereas the smaller subspecies was restricted to the south. Larger body size, however, usually involves higher energy demands. Franz Josef Land is known for its numerous polynyas which remain open during the entire winter season (Zenkevič 1963). Abundant food resources and feeding close to the colony may increase feeding efficiency (Wesławski et al. 1994). The use of distinct wintering areas may have reinforced the differentiation.

There is some evidence of differences in migratory habits between Svalbard and Franz Josef Land populations. The Svalbard population 
winters in southwest Greenland waters (Norderhaug 1967), whereas the wintering grounds of the Franz Josef Land population are not known. Considerable numbers of little auks winter in the northern region of Novaja Zemlja. As the little auk population in Novaja Zemlja is estimated at several thousand pairs only (Golovkin 1984), the birds wintering there may originate from Franz Josef Land (Rutilevskij \& Uspenskij 1957; Butev 1959). The early arrival of little auks at their breeding grounds in Franz Josef Land (February and early March; Gorbunov 1932) suggests that they winter relatively close by; some birds may even winter in the polynyas of this region.

The discovery of little auks in the Bering Sea, along with evidence that some of these birds belong to an established population (Bédard 1966; Breckenridge 1966; Holmes 1968) and the fact that these specimens have been assigned both to Alle a. alle and A. a. polaris (Sealy et al. 1971) does not clarify the situation. However, Day et al. (1988) concluded that all the little auks found in the Bering Strait belonged to the niminative subspecies. Two birds from Severnaja Zemlja in the collection of St. Petersburg Museum differ so much in their measurements that one could be assigned to the subspecies polaris and the other to alle.

Some differences in body size are also found among $A$. a. alle specimens from different areas (Tables 1 and 5). Interpretation of these differences is difficult because of the various measuring techniques used. However, even when measurements were obtained by the same method, differentiation of the little auk populations within the Svalbard archipelago could be confirmed. Birds from Bjørnøya tend to be smaller than those from Spitsbergen (Table 2).

There were no statistically significant differences in the size of eggs from the three areas (Bjørnøya, Spitsbergen and Franz Josef Land), but the mean values corresponded with the differences found in body size. However, these differences should be interpreted with caution due to the small sample sizes (Bjørnøya and Franz Josef Land) and different sample years (Table 4).

The majority of the little auks in the colonies visited in Franz Josef Land occupy holes and crevices in the walls of rocky cliffs, the same breeding habitat occupied by black guillemots. This may lead to interspecific competition for nesting sites. On several occasions we observed little auks displaying black guillemots from cliff ledges and even chasing them in the air. In Franz Josef Land only small colonies of little auks were observed in easily accessible talus slopes, which is not true for little auks in Svalbard.

The apparent preference for cliffs to talus slopes in the visited colonies in Franz Josef Land can partially be explained by the easy accessibility of the cliffs which allow earlier breeding, a factor which is crucial in the extremely short Franz Josef Land summer, and protection from mammalian predation which is high in the talus colonies. At least one arctic fox Alopex lagopus was observed almost permanently penetrating the little auk colonies at the foot of Rubini Rock, and polar bears Ursus maritimus were noted to cause considerable losses in these colonies (Stempniewicz 1993).

Predation by the glaucous gull was, however, negligible both in the vulnerable cliff colonies and in the talus colonies. In 1992 eight glaucous gull pairs nested at Rubini Rock. They hunted mainly young Brünnich's guillemots and kittiwakes Rissa tridactyla. During 143 hours of observation, only 27 incidents of patrolling gulls were observed in the little auk colony at Rubini Rock, and only one successful attack on a little auk fledgling. In Spitsbergen, glaucous gulls persecute little auks much more intensely (Stempniewicz 1995).

In Franz Josef Land, little auks begin breeding about 10 days earlier and leave the colony about 15-20 days later than they do in Svalbard. Thus, their breeding season seems to be more protracted and less synchronised than in Svalbard. The total duration of the little auk breeding period (comprising eggs and chicks present in the colony) was calculated to 67 days in Spitsbergen and to 86 days in Franz Josef Land. A lower synchronism in Franz Josef Land is probably a consequence of less intense predation by glaucous gulls and shorter feeding ranges there, which tend to make synchronisation of colony attendance and fledging less essential for survival (Stempniewicz 1986; Wesławski et al. 1994). The intense activity of mammalian predators which damages little auk nests at different breeding stages may cause a lengthening of the egg-laying period (replacement clutches). However, great caution is needed when interpreting phonological differences due to prominent interannual climate variations in the High Arctic.

Demme's (1934) suggestion that young little auks leave the breeding colony in Franz Josef Land in winter plumage was not confirmed by us. However, the percentage of white-bibbed 
nestlings was much higher than that found in Spitsbergen (Stempniewicz 1989). White-bibbed young birds may elude the first pre-basic moulting involving lower face and throat areas and thus save time and energy after fledging. Parent little auks start moulting while they are still feeding their chicks. Moulting during breeding creates an additional energy demand and is only possible under conditions of easily available food and numerous feeding grounds close to the breeding colony. By starting to moult breast feathers before breeding is completed, adult little auks also save time and energy later. Both these features of young and adult $A$. a. polaris may be considered as adaptations to the extremely severe and short summer season in Franz Josef Land.

Acknowledgements. - We would like to thank our colleagues from the expeditions to Franz Josef Land (RUS-NOR-POL 9193) and Bjørnøya 94 for their help during field work. Special thanks are due to J. M. Weslawski from the Institute of Oceanology PAS. The Norwegian Polar Institute kindly allowed us to use the cabin in Revdalen, Bjørnøya. Financial support was received from the University of Gdańsk (grant nr. BW/1140-500872 and 805 ). We are grateful to three anonymous referees for English language assistance and constructive comments to the manuscript

\section{References}

Bédard, I. 1966: New records of alcids from St. Lawrence Island, Alaska. Condor 68, 503-506.

Bédard, J. 1985: Evolution and characteristics of the Atlantic Alcidae. Pp. 1-51 in Nettleship, D. N. \& Birkhead, T. R. (eds.): The Atlantic Alcidae. Academic Press, LondonToronto.

Birkhead, T. R. \& Nettleship, D. N. 1987a: Ecological relationships between Common Murres, Uria aalge, and Thick-billed Murres, Uria lomvia, at the Gannet Islands. Labrador. I. Morphometrics and timing of breeding. Can. J. Zool. 65, 1621-1629.

Birkhead, T. R. \& Nettleship, D. N. 1987b: Ecological relationships between Common Murres, Uria aalge, and Thick-billed Murres, Uria lomvia, at the Gannet Islands, Labrador. II. Breeding success and site characteristics. Can. J. Zool. 65 , 1630-1637.

Birkhead, T. R. \& Nettleship, D. N. 1987c: Ecological relationships between Common Murres, Uria aalge, and Thick-billed Murres, Uria lomvia, at the Gannet Islands, Labrador. III. Feeding ecology of the young. Can. J. Zool. 65, 1638-1649.

Bradstreet, M. S. W. 1982: Pelagic feeding ecology of Dovekies, Alle alle, in Lancaster Sound and Western Baffin Bay. Arctic $35,126-140$.

Breckenridge, W. J. 1966: Dovekie on Diomede Island, Alaska. Auk 83, 680 .

Butev, W. T. 1959: Zimovka ptic na severe Novoj Zemli (Birds wintering in the north of Novaja Zemlja). Ornitologia 2, 99 101.

Day, R. H., De Gange, A. R., Divoky, G. J. \& Troy, D. M.
1988: Distribution and subspecies of the Dovekie in Alaska. Condor 90, 712-714.

Dement'ev, G. P. 1951: Otrjad Cistiki. Pticy Sovetskogo Sojuza (Alcidae. Birds of the Soviet Union). Sov. Nauka, Moskva, Pp. 169-240.

Demme, N. P. 1934: Ptičij bazar na Skale Rubini (Birds' colony on the Rubini Rock (Hooker Island, Franz Josef Land) Trudy Arkt. Inst. 11, 55-86.

Flint, V. E. \& Golovkin, A. N. 1990: Pticy SSSR. Čistikovye (Birds of the USSR. Alcidae). Nauka, Moskva. $207 \mathrm{pp}$.

Golovkin, A. N. 1984: Sea birds nesting in the USSR: status and protection of populations. Pp. 473-486 in Croxall, J. P., Evans, P. G. H. \& Schreiber, R. (eds.): Seabirds of the World: Their Status and Conservation. International Council for Bird Preservation. Cambridge, England.

Gorbunov, G. P. 1932: Pticy Zemli Franca Josifa (Birds of Franz Josef Land). Trudy Arkt. Inst. 4, 1-234.

Holmes, R. T. 1968: A Dovekie on the Pribilov Islands, Alaska (Plautus alle record). Condor $70,86$.

Kozlova, E. V. 1957: Podotrjad Cistikovye, Fauna SSSR, Pticy (Suborder, Alcae, Fauna of USSR, Birds), Vol. 2. MoscowLeningrad. Pp. 114-143.

Løvenskiold, H. L. 1954: Studies on the avifauna of Spitsbergen. Norsk Polarinst. Skr. 103. $131 \mathrm{pp.}$

Norderhaug, M. 1967: Trekkforhold, stedstrohet og pardannelse hos alkekonge på Svalbard. Fauna 20(4), 236-244.

Norderhaug, M. 1980: Breeding biology of the Little Auk (Plautus alle) in Svalbard. Norsk Polarinst. Skr. 173, 1-45.

Roby, D. D., Brink, K. L. \& Nettleship, D. N. 1981: Measurements, chick meals and breeding distribution of dovekies (Alle alle) in north-west Greenland. Arctic 34, 241-248.

Rutilevskij, G. L. \& Uspenskij, S. M. 1957: Fauna ptic i mlekopitajuščih Centralnoj Arktiki (Fauna of birds and mammals of the Central Arctic). Trudy. Arkt. Inst. 205, 5-18.

Salomonsen, F. 1944: The Atlantic Alcidae. The season and geographical variation of the auks inhabiting the Atlantic Ocean and adjacent waters. Gøteborgs Kunlinga Vetenskapsoch Vitterhets-Samhalles Handlingar, Serie B 3, 1-138.

Salomonsen, F. 1972: Zoological and ecological problems in artic birds. Proc. Intern. Ornithol. Congr. 15, 25-77.

Sealy, S. G., Bédard, J., Udvardy, M. D. F. \& Fay, F. H 1971: Records and zoogeographical notes on the birds of St. Lawrence Island, Bering Sea. Condor 73, 322-336.

Spring, L. 1971: A comparison of functional and morphological adaptations in the Common Murre (Uria aalge) and Thick billed Murre (Uria lomvia). Condor 73, 1-27.

Stempniewicz, L. 1980: Factors influencing the growth of the Little Auk, Plautus alle (L.), nestlings on Spitsbergen. Ekol. Pol. 28, 557-581.

Stempniewicz, L. 1981: Breeding biology of the Little Auk Plauns alle in the Hornsund region, SW Spitsbergen. Acta Ornithol. 18, 141-165.

Stempniewicz, L. 1986: Factors causing changes in the rhythm of attendance of the Little Auks, Plautus alle (L.), at a colony during the breeding season in Svalbard. Ekol. Pol. 34, $247-$ 263.

Stempniewicz, L. 1989: Dovekie juvenile plumage dimorphism. Colonial Waterbirds 12, 123-125.

Stempniewicz, L. 1993: The polar beef Ursus maritimus feeding in a seabird colony in Frans Josef Land. Polar Res. 12, 33 36.

Stempniewicz, L. 1995: Predator-prey interactions between glaucous gull Larus hyperboreus and Little Auk Alle alle in Spitsbergen. Acta Ornithol. 29, 155-170.

Stenhouse, J. H. 1930: The Little Auk Alle alle (polaris sub 
species nov.) of Franz Josef Land. Scottish Naturalist 182, $47-49$.

Storcr, R. W. 1952: A comparison of variation, behavior and evolution in the sea bird genera Uria and Cepphus. Univ. Calif. Publ. Zool. 52, 121-222.

Strauch, J. G. Jr. 1985: The phylogeny of the Alcidae. Auk 102, $520-539$.

Svensson, L. 1975: Identification guide to European Passerines. Naturhistoriska Riksmuseet. Stockholm.
Westawski, J. M. 1993: The comparison of West Spitsbergen and Frans Josef Land marine coastal ecosystems. Studia $i$ Materiaty Oceanologiczne (SIMO) 64, 331-341.

Wesławski, J. M, Stempniewicz, L. \& Galaktionov K. 1994: Summer diet of seabirds from the Frans Josef Land archipelago, Russian Arctic. Polar Res. 13, 173-181.

Zenkevič, L. A. 1963: Biologia morej SSSR (Biology of the seas of the USSR). Nauka, Moscow. 735 pp. 